\title{
GENDERED FACTORS OF CHINESE MULTI-LOCALITY MIGRATION: \\ THE NEW ZEALAND CASE
}

Manying Ip and Liangni Liu

\begin{abstract}
Chinese female migration always stands apart from New Zealand mainstream migration. Historically, Chinese women were restricted by openly discriminatory legislation and selective manipulation of immigration policies until the introduction of new immigration policy in 1987. Contemporarily, the multilocality strategy (popularly labelled as 'astronauting') that Chinese women and their families pursue has attracted much media attention. This paper will explore the gendered factors of Chinese migration within the New Zealand context and examine the grounds on which some of these popular perceptions have developed. The researchers found that in recent years Chinese women greatly outnumbered their male counterparts not just because they were 'wives left behind in New Zealand', but also because more Chinese young women migrated to New Zealand on their own initiatives. By critically analysing two sets of data sources (the New Zealand Census and New Zealand Immigration Services), we found that the number of female principal applicants in the General Skilled Category is higher than that of male. The crucial indicator is that Chinese women are actively involved in the migration decision-making process and may even be the driving force of this mobility. Further empirical evidence also shows that women have played lead roles in the return migration processes, giving impetus to transnational movements and multi-locality migration.
\end{abstract}

\section{INTRODUCTION}

This article posits that gendered factors were, and still are, important elements in the analysis of Chinese migration, especially multi-local and transnational movements, which have been largely left unexamined. We propose to investigate the female factors in migration, with special consideration to see how 
these have affected the initial emigration decision, the subsequent returning movement and any further onward relocation. We propose to examine this by looking at the New Zealand case, tracing the pattern of Chinese migration and the subsequent transnational movements from early historical times to the present.

Although 'transnationalism' is a comparatively modern concept in migration studies, the phenomenon of return migration and onward migration is as old as the migration process itself. As long as there was an outflow of people, there was always a counterflow (Skeldon 1994: 6). A certain proportion of emigrants from any source country have always become returnees later on. In earlier centuries, the transnational movements were much slower since transport was dependent on boats and trains.

Historically, the male-female ratio of the ethnic Chinese population in New Zealand was extremely unbalanced because Chinese women were restricted by openly discriminatory legislation and selective manipulation of immigration policies until the introduction of new immigration policy in 1987. Chinese women assumed the role of 'gold mountain wives' (Ip 1995b) staying in the home villages while their husbands worked as itinerant labourers to support them with remittances. They became the crucial factor for their husbands' periodic travels, from New Zealand back to the home villages in China. Contemporarily, the multi-locality strategy (popularly labelled as 'astronauting') that many new migrant Chinese families pursue has resulted in a dramatic reversal of the gender balance, with large numbers of ethnic Chinese females residing in New Zealand while their men live and work in Asia, commuting periodically to New Zealand. In popular media, these women have been called, rather dismissively and negatively, as 'astronauts' wives'.

Some unexpected findings have surfaced recently, pointing to the development of a highly significant new trend, yet under-studied, in modern Chinese migration. We have found that Chinese women now greatly outnumber their male counterparts not just because they were 'wives left behind in New Zealand', but also because more Chinese young women migrate to New Zealand on their own initiatives. By critically analysing two sets of data sources (from the New Zealand Census and New Zealand Immigration Services [NZIs]), we found that the number of female principal applicants in the General Skilled Category is in fact higher than that of male applicants. This trend has been so far overlooked. The crucial indicator is that Chinese women are now actively involved in the migration decision-making process and may even be the driving force of this mobility. Further qualitative empirical evidence supports the 
hypothesis that women have played lead roles in the return migration processes, giving impetus to subsequent multi-local movements.

\section{CHINESE FEMALE MIGRANTS IN NEW ZEALAND'S HISTORY}

Chinese women already featured in New Zealand's first census of 1867: there were six Chinese females and a total of 1,217 Chinese males. Early migrant communities worldwide are commonly known for their gender imbalance, with males far outnumbering the females. The harshness of pioneer life and the instability of frontier societies did not favour female settlement. However, the gender-ratio of the New Zealand Chinese community remained severely unbalanced until very recent times. It was not until 1991 that the Chinese gender-ratio achieved a balance of 99 males to 100 females. The 124 years that took the New Zealand Chinese community to attain gender-ratio normalcy should be a powerful reminder of the long struggles that the Chinese faced as a community. The exceptionally lengthy process as well as the severity of the imbalance was the result of New Zealand's discriminatory immigration policies on the one hand, and China's traditional cultural practices - partly borne out of harsh economic necessities - on the other.

The migration patterns of Chinese to New Zealand have largely been voluntary (as opposed to forced labour), not dissimilar to that of arrivals from the United Kingdom, New Zealand's largest migrant source country. Many female migrants, especially single women from the United Kingdom who chose to come to New Zealand, did so largely because they saw opportunities of personal advancement in a less constrained society. Single British female migrants were highly welcomed in New Zealand; they were needed as domestic servants, and more importantly, as potential marriage partners to the British male settlers.

Chinese female migration stood in stark contrast to the British mode. Chinese women migrants came as wives, or much more rarely, as daughters of Chinese men who were already naturalised citizens of New Zealand. Early migration records showed no instances of Chinese migrating together as a family (Murphy 1995). There was absolutely no record of any Chinese female migrating to New Zealand on her own, as a pioneer migrant. In other words, Chinese females migrated to New Zealand only as an appendage of male migration; there was no independent female migration to speak of. This was in direct contrast to female migration from the United Kingdom, when independent British women were recruited as domestic helpers or simply welcomed to bolster the female population of the new land (Rogers 1996). 
A proper understanding of Chinese female migration has to be set in the broader background of Chinese migration in general. The Chinese were designated 'undesirable immigrants' by the New Zealand government. New Zealand was to be preserved as a haven for exclusive settlement of the British, and coloured migrants were not welcomed. The Chinese were brought in as goldminers in 1866 when the Otago goldfields badly needed labourers, but the government's intention was that they should only be itinerant labourers, and not settle. Even when their frequently cited virtues of industriousness, inoffensiveness, and docility were counted, they were deemed to be 'too different' (from British migrants) to become good settlers. The tenor of a parliamentarian in 188 o was rather typical, 'The Chinaman, however docile, however imitative, and however industrious he might be, in so far as he knew nothing about free government, were unfitted to take any part in the government of a free country' (New Zealand Parliamentary Debates 1880: 91) Governor George Grey similarly saw the Chinese as a source of danger to New Zealand. In an 1879 memo to Parliament he wrote, 'The presence in this country of a large population of Chinese ... would exercise a deteriorating effect upon its civilisation.' (Appendices to the Journal of the House of Representatives 1879).

The opinions of New Zealand politicians quoted above showed very clearly that the Chinese were not regarded as a true settler community. If Chinese men were barely tolerated in spite of their recognised industriousness (and therefore potential economic contribution), there would be no reason at all for Chinese women to be allowed into New Zealand. What suited the New Zealand government best would be for the women to be kept out, so that the Chinese men would eventually return to China. In the interim years Chinese men could just be itinerant, commuting labourers. As far as New Zealand was concerned, Chinese women could just remain a factor to ensure that all the Chinese itinerant workers eventually leave. New Zealand legislation, which kept the Chinese women out also, ensured that Chinese families became multilocal.

In Chinese tradition, sojourning was a time-honoured necessity and a survival strategy. Sojourning was not limited to living in a foreign country. Quite often it was necessary for the men to work and live temporarily in another location, usually a city or town where more money could be made - away from the home village. 'Sojourning is a concept well served by the Chinese lexicon, which possesses many terms to express the ideas of roving, lodging and being away from home temporarily. Indeed the sojourner has long been a familiar 
figure in the Chinese landscape' (Pan 1998:47). Men in traditional China often pursued their occupational calling away from home. According to sociologist G.W. Skinner '...they were sojourners, and where they sojourned were typically more urban than their native places...pursuing that calling away from home, in places offering richer rewards, was a "mobility strategy"' (Pan 1998: 47 citing Skinner 1976).

In this mobility strategy for survival, the Chinese female's position was to serve as an anchor at home, and also as a magnet to ensure that the sojourners would eventually return. Chinese women were expected to wait patiently for their men's return visits to the home village. If they were lucky, they would become pregnant in the process and sons would be born. Then it was their duty to raise these children devotedly to preserve the patriarchal lineage. They would also serve their husbands' parents obediently and respectfully at the same time. It was a life of 'live-widowhood', as portrayed by a mournful 'Gold Mountain Song' (Hom 1987).

\section{Do not marry your daughter to a Gold Mountain man \\ He would not be home in one full year out of ten. \\ Spiders webs would cover half of her bed \\ While dust covers fully one side.}

More prosperous and successful Chinese merchants would sometimes take secondary wives, usually local women, at their ports of call. In New Zealand, some Chinese men married European or Maori women even though they might already have wives in China. Others who could afford the poll tax, and whose wives would brave the English test on their arrival, might send for their women when they accumulated enough wealth. In New Zealand, the gendered effects of legislative restrictions can be easily seen; it was largely responsible for the extreme imbalance of male-female ratio noted at the beginning of this article.

CHINESE WOMEN IN THE EYES OF NEW ZEALAND POLICY MAKERS

While there were no specific laws against Chinese women's immigration, historical records clearly showed that they were regarded by the New Zealand authorities as potentially more menacing, because they could procreate: the emergence of local-born Chinese babies who were therefore 'British subjects' would have been most upsetting for the early Pakeha settlers who wanted to keep New Zealand white. In 1907, during the debate on the Chinese Immigrants Amendment Bill, the arrival of thirteen females, referred to as 'the largest number of Chinese women arriving ....in the country's history' led to 
openly discriminatory public pronouncements: 'The result of this is that we are having New Zealand-born Chinese children, who are, unfortunately, brought up to live according to the habits of Chinese...' (NZPD 1907: 839-40). Chinese customs and culture was regarded as somewhat evil and undesirable, and ethnic Chinese children, even when born in New Zealand, were not good enough to be considered as 'British subjects', a status accorded automatically to the offspring of European settlers. In this way, the Chinese women's gender made them even more dangerous and undesirable than their men. The assumption was biased both in race and in gender.

The same parliamentary debate continued, 'There are in New Zealand at the present time fifty-five Chinese women. I think these figures alone will go to prove conclusively that it is about time something is done to deal with this matter.' It should be noted that these 55 Chinese women lived in a community with over 2,500 Chinese men, and the numbers of both were in rapid decline. ${ }^{1}$

In the same year, a reading test which empowered the customs officer at the port of entry to pick 'one hundred English words at random' to test Asian immigrants was introduced (Statutes of New Zealand 1907). Chinese women of the time seldom saw or spoke to men outside their own families, even when they were in China. To face the prospect of being orally examined by a white man in a foreign language must have been extremely daunting. The hurdles against women that prevented them from joining their husbands made many women apprehensive and marginalised long after their entry. Some would refuse to speak English altogether. All were condemned to very lonely existence with little social support - there were simply too few Chinese women in New Zealand (see Ip 1991a, 1991b).

\section{REPATRIATION AND RE-MIGRATION OF LOCAL-BORN CHINESE GIRLS}

Another related phenomenon that has so far escaped serious research was the repatriation of local-born Chinese girls. The returnee trend of young Chinese females further depleted New Zealand's female Chinese population. For example, there were only twenty-six Chinese females in the 1896 census, and thirtytwo in 1901, with eleven of them under fourteen years ( $\mathrm{Ng}$ 1993: 100). Among scholars on the overseas Chinese, it is widely known that parents routinely sent local-born Chinese boys back to China for a 'proper Chinese education'. Less well known is the phenomenon of sending girls home. Based on oral history evidence undertaken by the first author, the reason for sending local-born girls home was to ensure they would find proper marriage partners in future (see Ip 
1990, 1996). Local-born Chinese girls, if they were raised in New Zealand, were often disparagingly referred to as 'joke-sing', literally bamboo pole, meaning that they were empty (of Chinese culture) uncouth, and unrefined. Lily Doo, a Canadian-born woman whose mother was also Canadian born, explained why she herself was sent back to China, (Lily subsequently married a New Zealand merchant's son with the help of a matchmaker). According to Lily:

...Chinese men in Canada preferred to make trips back to China to select their wives there, whereas European men would seldom marry Chinese girls. There was a surplus of Canadian-Chinese girls. Anyway, their families would rather they became concubines of Chinese men than marry westerners. On the other hand, westerners looked down on Chinese women and would not marry them (Ip 1990:51).

Lily's own mother became the fourth concubine of a man twenty years her senior.

To ensure that their daughters would marry well, New Zealand-born Chinese girls made the transnational movement homewards, and after a few years of immersion in Chinese culture, they might be able to find suitable marriage partners with the help of marriage brokers. They would marry either New Zealand Chinese men, or quite often, Chinese men in other foreign countries. The overseas Chinese transnational network also extends to finding marriage partners (Ip 1996: 89-105).

THE FEMALE FACTOR IN LEGISLATIVE RESTRICTIONS 1920S TO 1940 S

In 1920 New Zealand's doors were closed tightly against coloured immigration by means of the permit system. All prospective immigrants required an entry permit, which the Minister of Customs had the right to grant or decline. No criterion for selection was given. No reasons would be given for the granting or refusal of a permit. There was no appeal. The system had no overt racial clause and was designed to be inscrutable. In reality it was an extremely powerful instrument to keep 'aliens' out and to keep New Zealand white (Price 1974: 96; also Brawley 1993).

A quota was in force according to a special negotiation between the New Zealand government and the Chinese Consulate, allowing 100 permanent entry permits each year to be issued since 1921 to Chinese. By 1925 women were excluded from this quota. A confidential internal Customs Department memorandum stated: 'This was presumably adopted as another means of preventing 
the Chinese population from increasing' (Labour Department 1950:3). The ineligibility of females for the permanent entry quota remained a crucial factor of continued Chinese transmigration: Chinese men had to continue moving between China and New Zealand because their wives and children remained in China. Chinese women were kept out totally until some minor relaxation in the 1930s. In 1935 a concession of ten permits for the wives of Chinese born in New Zealand was introduced. Permanent Chinese residents were not permitted to send for their wives.

The absence of Chinese females ensured that the Chinese community remained a community of bachelor males, with few anchors in the host country. It was only by the adoption of the highly flexible multi-local strategy of transmigration that Chinese could continue to stay in New Zealand. The New Zealand policy makers' design, however, was for the Chinese community to eventually diminish by attrition.

The policy of restriction, segregation and hoping that the Chinese would die out without their women did not change until the eve of the Second World War. China was under Japanese attack a decade before the 1941 attack on Pearl Harbour. Japan attacked Northeast China in 1931 and established a puppet regime under the last Manchu Emperor Puyi in 1933, calling it Manchukuo. Beijing (called Peiping at that time) was occupied in 1937, and the advancing Japanese armies rapidly overran important coastal cities, including the home villages of the New Zealand Chinese - the Canton region in south China. The escalation of the Sino-Japanese War led to the temporary opening of New Zealand to the wives and minor children (aged below sixteen years) of Chinese men who had permanent resident status in the country. It was a special one-off temporary-permit concession, approved by cabinet as a humanitarian gesture in February 1939. Originally designed as a short-term measure offering the women and children refuge for two years only, and carefully supplemented by various provisions to ensure that all these refugees would eventually be repatriated, the 1939 concession was to become a significant milestone in the history of Chinese settlement in New Zealand - a totally unintended outcome of the cabinet's hesitant and half-hearted open door policy.

The period for this temporary permit application was also very short-lived. The first permits were granted in June 1939, and the concession was withdrawn in early 1940 ' '...following complaints that Chinese fruiterers were employing their wives and children in their shops while their assistants were starting their own businesses, in some cases taking over shops vacated by European fruiterers who had joined the forces' (Labour Department 1950:3). 
The remarkable speed with which the Chinese applied for their families to join them belies the popular theory that all Chinese wished to return home. By the end of 1939 permits had been issued for the temporary admission of 240 wives and 244 children. Considering that the resident Chinese population in New Zealand was only around 2,500 at the time of the 1936 census, we can see that probably everyone eligible to apply for bringing out his wife and children did so. The stringent and expensive conditions of the concession did not deter them. According to Nigel Murphy (2000:240-244) each application required:

a. a deed of covenant executed by the husband and two other sureties that all cost on any public institution would be paid,

b. a bond for 500 pounds guaranteeing that the wife would take all children born to her in this country away from New Zealand, and that the husband would 'give all necessary consents for this. ${ }^{2}$

c. If the application was successful, the permit would only be issued subjected to the condition that 'on arrival, the sum of 200 pounds was deposited with the Collector of Customs, together with a deed to the effect that the deposit would be forfeited if the conditions of the permit were not complied with.3

The extreme care taken shows that the 1939 Concession was not designed as an open door to the Chinese. The extraordinary precautions that the New Zealand government undertook require examination. To enforce the eventual repatriation of the refugee women and any babies who would be born in New Zealand, the legal status of these babies had to be limited. Since there was no legal means of forcing a child born in New Zealand to alien parents to leave the country, the huge bond was required to ensure their eventual removal.

Even more problematic for the New Zealand government, was the prospect of these children born during the two-year concession period insisting on returning to New Zealand some time in future, even if they were repatriated initially. All ethnic Chinese, including local born and naturalised citizens, were required to have 'Certificates of Registration' (commonly known as re-entry permits) in order to re-enter New Zealand. So in May 1939 the regulations were amended, stipulating that only people of fifteen years or over could obtain a Certificate of Registration. A confidential Customs Department memorandum explained the reasons behind such an unusual move: 
... It has recently been decided to grant permission in approved cases for the wives and minor children of Chinese residents of the Dominion to enter New Zealand for a period of two years, but before doing so it has been considered advisable for the Minister of Customs to be vested with power to refuse to grant Certificates of Registration authorising the re-admission... of children who are born in New Zealand to Chinese women visiting their husbands in this country under the above-mentioned concession (Labour Department, Gisborne).

Clearly, the New Zealand government's legislative measure was to prevent Chinese families settling in New Zealand. The Chinese would have to continue commuting - an ongoing process of transnational travels - if the government's plan was to succeed. Subsequent history and world events would render this precautionary regulation change superfluous, but once more, the potential power of the Chinese females was highlighted by the extraordinary measures taken by the Government to exclude their babies who might be born.

\section{CHINESE FEMALES DURING THE MODEL MINORITY PERIOD}

The World War lasted until late 1945, but the continual Chinese civil war (between the Nationalist government and the communists) delayed the planned repatriation of Chinese women and children. By late 1947, there were about 1,400 Chinese women and children holding temporary permits in New Zealand, including some 450 locally born babies. The Presbyterian Church made a strong representation to parliament on their behalf, and these families were allowed to stay.

The 1945 census showed that the Chinese population was just under 5,000, much the same as it was in 1881 - the fateful year when the Chinese Restriction Act was passed. The real difference lies in the significant (though still small) number of Chinese women in the population. Although the number was modest, it marked the beginning of a real community of Chinese families in New Zealand.

At the same time, many of the socially discriminatory policies were repealed or became inactive, ${ }^{4}$ while the actual immigration process of the Chinese remained as highly restricted as ever.

Official government policy favoured total assimilation of the small Chinese community already allowed residence in the country. In 1951, the Chinese 
were permitted to apply for naturalization. While the Chinese faced several more restrictive clauses than others, ten of them succeeded in gaining British citizenship by 1952. The first of this group was a young woman, Mabel Sang, who had entered New Zealand as a little girl. Local born Chinese women, like their male counterparts, rapidly rose in social status and economic power because of their success in education. They became the 'model minority' of New Zealand by adopting mostly New Zealand values. Owing to the lack of new immigrant input, most of the local Chinese community rapidly lost their heritage language proficiency. By all accounts, the Chinese were on the verge of being totally assimilated by the $198 \mathrm{os}$, when new immigration policies totally changed the scene.

NEW FEMALE IMMIGRANTS IN THE EARLY 1990 S

1987 marked a highly significant turning point of the Chinese community in New Zealand. In line with general economic deregulation and the opening of the country to the rest of the world, the fourth Labour Government established a new immigration policy based on personal merit irrespective of racial or national origin. It was not intended to be revolutionary, but what followed not only changed the component of the longstanding Chinese community, but also profoundly altered the ethnic composition of New Zealand, especially in the big cities. ${ }^{5}$

Census data clearly showed an upward trend in the New Zealand Chinese population between 1986 and 2006. Unlike the early Chinese migrants from Mainland China in the late nineteenth or early twentieth century, many of the new Chinese immigrants arrived from origin countries outside of China: Taiwan, Hong Kong, Singapore, as well as other parts of Southeast Asia, and even from South Africa and Australia (Ip 1998: 286-291). Statistics showed that during the period of 1987 to 1996, Hong Kong and Taiwan were the two main source countries of Chinese migrants. After 1996, Mainland China became the main source country of Chinese migrants again.

Since the 1991 census, the number of Chinese females exceeded that of Chinese males (Figure 1). The following census showed that the Chinese females continue to outnumber Chinese males. The latest census figures of 2006 gave the number of Chinese females as around 77,000 (while the Chinese males numbered around 71,000), making the total number of ethnic Chinese just over 148,000 (Statistics New Zealand 2001). 


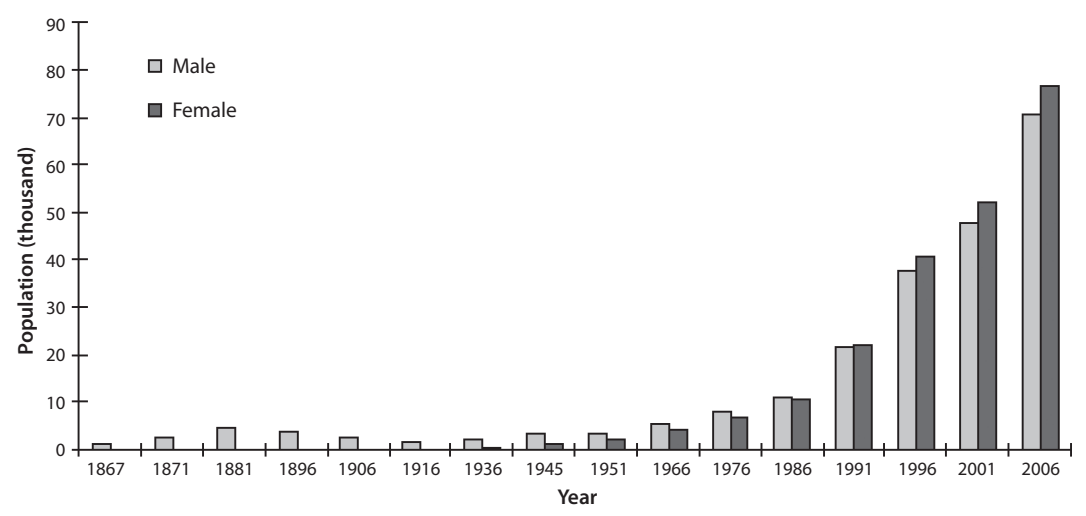

Figure 1. Chinese in NZ: Females cf. Males 1867-2006 Census

(Source: Statistics New Zealand)

The gender ratio imbalance in New Zealand Chinese observed before 1987 has noticeably been reversed since 1991, with females continuously outnumbering males. Previous research attributed the cause of this reverse sex ratio difference to the 'astronauts' wives' phenomenon (Ho, Ip and Bedford 2001: 24-30; also Ip 2002; Vong 2002). It mainly appeared amongst immigrant families from Hong Kong and Taiwan, in which the income earners (mainly husbands) returned to their home country to continue their jobs, while the rest of their families depended on the financial support from Asia to live in New Zealand.

Since the new immigration policy has recognised personal merit, measurable by youth, educational qualifications, professional experience, business track record as well as settlement capital, most of the new Chinese immigrants were middle class professionals or business people. Most migrants from Hong Kong came to New Zealand under the business category while Taiwan people preferred to come under the general skills category after the introduction of the point system in 1991 (Bedford, Ho and Lidgard 2000). Compared with the early Chinese migrants who came to New Zealand to make a living, these new migrants considered themselves exiled for political reasons, such as the fear of the hand-over of Hong Kong to China in 1997 and the political tension between Mainland China and Taiwan in the late 1990s. Their incentive for migrating to New Zealand was also a conscious choice for a better quality of life and education for their children.

Media attention tended to focus on the moneyed class who built 'ostentatious houses' in sought-after school zones, and absentee parents who flew back and 
forth to their Asian origin countries, leaving their children to take advantage of New Zealand's free education. The mid 1990 os anti-Asian backlash, which reached a height in the 1996 pre-election campaigns led by the xenophobic New Zealand First Party, was largely fuelled by strong public resentment against the highly visible behaviour of the so-called 'astronaut parents' and their 'parachute kids' (Ho 2002). As mentioned above, these aeronautical terms rather vividly capture the family arrangements of some new migrants within this post-199os cohort. Often the chief breadwinner of the family, usually the man, would fly periodically back to his wife and children left at the new destination, while continuing with his business in Asia. Sometimes it was alleged, the children were like airdropped paratroopers, left behind on their own in the new destination.

Academic studies of this phenomenon generally agree that the practice has its roots in the new migrants' desire to have the best of both worlds, and that frequent commuting is routinely practiced by migrants of all ethnic groups, not just Chinese (Friesen and Ip 2001: 24-30). However, the specifically noticeable large scale short-term commuting to and from destination countries (not just in New Zealand but also in Canada and Australia) was popular among Hong Kong people before 1997. The fear and uncertainty of what might happen when the British colony would become part of Communist China propelled worried middle class Hong Kongers to leave the prosperous metropolis to seek a safe haven elsewhere. They were the 'reluctant exiles' whose sole reason of leaving was to fulfil '...the residence requirement for a foreign passport, which was sought as an insurance policy against things going wrong after 1997' (Skelton 1994: 6). Since many of the females in this cohort had no intention of staying long-term, they were merely 'clocking time in a strange land, with their hearts divided between their old homes and their children in New Zealand....' (Ip 1995b).

The most accurate measure of the stability of settlement, the well-being, and economic status of any ethnic group is their profile yielded by the national census. Prior to 1996, it was difficult to glean much meaningful information from the census statistics on the Chinese in general, and that of the Chinese female in particular. The very positive statistics of the established Chinese New Zealanders in education, income, professions, and employment tended to obscure the dire situation of many of new Chinese migrants. In 1999 Statistics New Zealand finally subdivided the Chinese population into three groups: the New Zealand born, the 'established' who had been ten or more years in New Zealand, and the 'new' Chinese who arrived within the ten years before the 1996 census. 
The crucial indicator of successful settlement is the labour market measure. This point was stressed by Manying Ip at the historic New Zealand Population Conference in 1997:

...probably there is no better gauge to measure a migrant community's successful settlement than by looking at its employment status profile. When a new arrival finds a job or starts a business, it marks the crucial milestone of sinking roots, the beginning of the long process of social and economic integration by which the immigrant will derive steady income as well as acquire a circle of work mates and friends.

The following sections provide an analysis of various aspects of Chinese females in New Zealand based on the 1996 census results. Among the total of 32,835 Chinese females nationwide, it was found that they were significantly under-employed. Barbara Thomson (1999) characterized the nation's Chinese women as having 'fewer employed, more not in the labour force, and their patterns dominated by recent immigrants.' A closer analysis of the working age 'new Chinese' females (about 20,000) who arrived in the ten years before the 1996 census, shows that a very high percentage (63 percent) were 'not in the labour force, with 20 percent of these officially unemployed. Among those new Chinese females who had work, 13 percent of them were employers, and an additional 5 percent were self-employed, with no employees (Ip 2002). The failure of these new Chinese women to find work, and their high percentage of self-employment, are both signs that of inherent hindrances in the job market, preventing them from finding suitable employment in spite of the successful track record which many of them possessed prior to migration.

The new Chinese females are very well educated: with 25 percent of the cohort having completed tertiary education. Fourteen percent are university graduates, which is twice the New Zealand proportions of females who are similarly qualified. This comes as no surprise, mainly because the new immigration policy targets the highly skilled and highly educated. However, the occupations profile is much less sanguine. Although the percentage of managers is high (consistent with their self-employed status), the percentage of restaurant and hotel workers is higher than the national average, and 17 percent of the new Chinese females work as machine operators and in textile or apparel.

Corresponding to the bleak employment picture and the comparatively humble occupations that the new Chinese females found themselves in, their income level was 'well below the New Zealand average'. About 19 percent reported no 
or a loss of income in 1996, and many reported very low incomes.

The willingness of the new Chinese to come to New Zealand despite the comparatively unsuccessful economic outcome underlines the fallacy of the established theory that migration is motivated primarily by economic considerations. The theory is inapplicable to twentieth century migrants who are well educated, highly skilful and comparatively wealthy. When asked for their major reason for migration to New Zealand, the most common reply given by the new Chinese was that they came for the education and a better future for their children. The Chinese parents clearly made significant monetary sacrifices in taking the step of migration. The mothers would have interrupted their professional careers, given up an extensive family support network, and opted for a much less stimulating home life. If their husbands were frequent commuters, these women had to cope with all the challenges of settling in a new land as well as being a sole parent.

\section{NEW CHINESE FEMALES IN THE NEW MILLENNIUM}

As mentioned above, Hong Kong and Taiwan were the main source countries of Chinese migrants before 1996. However, a combination of factors occurred, including: immigration policy changes in 1995, and the onset of the Asian economic crisis in 1997, to bring a sharp decline in the number of migrants from Hong Kong and Taiwan. From 1996 to 2000, the number of immigration applications from these two regions dropped from over 10,000 to a few thousand, with a further decline to a few hundred. At the same time, immigrants from the People's Republic of China (PRC) started to increase from the mid-199os and this trend has continued (Figure 2). The data from New Zealand Immigration Services shows that the PRC contributed the second-largest number of residence approvals in New Zealand between 1997 and 2006 (68,275), just after Great Britain $(86,998)$ (NZIS 2007).

Apart from the significant change of the composition of the ethnic Chinese population in New Zealand, what has not changed much is the reversed sex ratio imbalance noticeable since the mid 199os. The female preponderance has remained. As mentioned in the previous section, the most recent census of 2006 shows that females continued to outnumber males. Although previous research suggested that such a sex ratio imbalance was due to the 'astronauts' wives' phenomenon, a more detailed analysis on the NZIS data reveals other important factors that might account for the imbalance. We shall proceed to analyse this phenomenon below. 


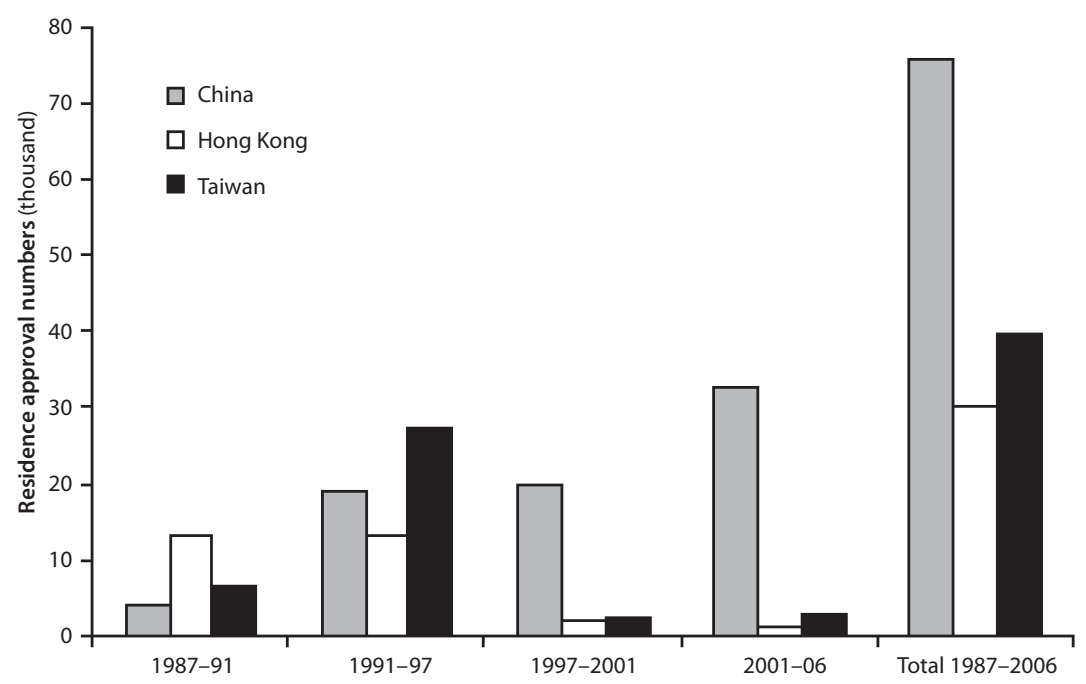

Figure 2. Accumulative NZIS residence approval number for three regions, 1987-2006 (Source: New Zealand Immigration Service)

Based on an analysis of the gender composition of the different categories of the residence approval data generated by the NZIS from the years of 1997/1998 to $2006 / 2007$ (NZIS 2007), it was found that the sex ratio imbalance partly results from the high ratio of older female migrants entering New Zealand under the family (parents) category. There was also an increase in Chinese women entering as spouses of New Zealanders. The sex ratio in the business or skilled migrant category was approximately even. Under the business category, there were 4,691 female applicants and 4,786 male applicants approved. Under the skilled category, 10,798 female applicants were approved compared with 10,969 male applicants approved. However, during the same period, NZIS admitted 5,145 Chinese females and only 4,324 Chinese males under the family (parents) category. The difference was 821. In part, the longer life expectancy of females contributed to the female advantage in the admission of parent category. There could also be the cultural factor that mothers (rather than fathers) are more ready to travel to New Zealand to look after their grandchildren. In the same period, NZIS also approved the residency applications of 5,506 Chinese females and 2,578 Chinese males under the family (marriage) category, with a difference of 2,918. Significantly, more females than males between twenty and forty years old were approved under the marriage category. This suggests that many of the new migrant females married New Zealand residents other than those 
newly arrived Chinese migrants. As a result, the difference in the number of females in the marriage and the parent sub-categories $(3,739)$ accounted for more than 100 percent of the difference in the total migrant approvals $(29,130$ female $-25,584$ male $=3,546$ ). We concluded that the greater proportion of female immigrants among the Chinese population is not only due to 'astronauts' wives', but also because more female migrants have been admitted into the country as parents or spouses of New Zealand residents.

The early Chinese migrant women who came to New Zealand mostly followed their husbands. Their role in the crucial decision-making of the migration process was minimal. In contrast, recent female arrivals were more active in migration decision-making, and in many cases, the protagonists of the migration initiative. This is reflected in the residence approval data of NZIS, where the gender ratio of the Chinese principal applicant under business/skilled categories was 62:38 percent (male: female) between 1991 - 2006. This pattern indicates that more women have been involved in the migration decision-making process and some of them even migrated on their own as sole migrants.

The early Chinese migrant women in the late nineteenth and early twentieth centuries migrated to New Zealand because of marriage ties. In contrast, for recent migrants under the family (marriage) category, marriage did not determine where they should be. Rather, marriage was a means of transferring to a new country to improve their future. Some women used marriage as a strategy to migrate to New Zealand, which indicates their independent decision-making process.

The demographic profile of the new Chinese female migrants in the new millennium shares the similar pattern of new Chinese female migrants before 1996. Most of the recent Chinese migrant women are highly educated. Both the 2001 and 2006 censuses show that the percentage of Chinese women who have tertiary educational qualifications and were born overseas are much higher than New Zealand female national average (Figure 3). The most recent census of 2006 indicates that 28.9 percent New Zealand Chinese women who are born overseas had tertiary qualifications, which is much higher than the statistics of the average New Zealand female (16.3 percent). ${ }^{6}$

However, their educational advantage unfortunately did not match their occupational levels. Based on the 2006 Census, 30 percent of Chinese females had full-time jobs, and 16 percent had part-time jobs, which accounted for only 46 percent of working-age Chinese females. Unemployed Chinese female comprised 5.8 percent, while the proportion of Chinese women not in the labour 


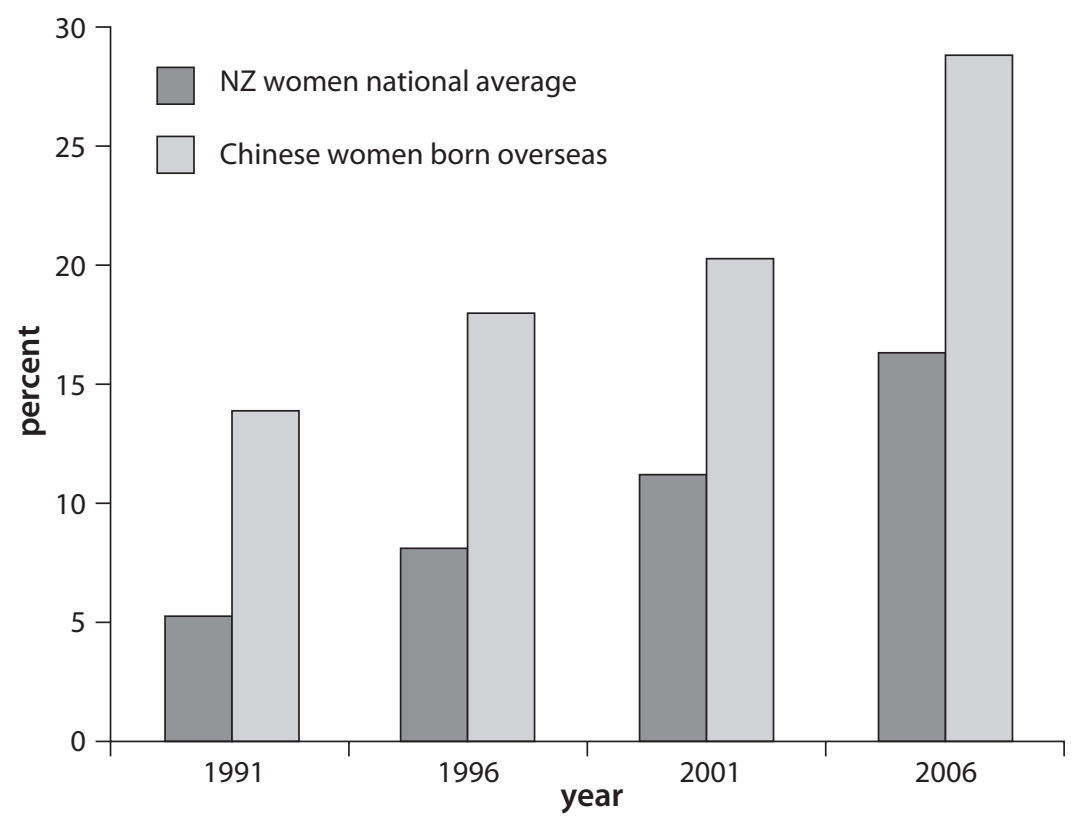

Figure 3. Tertiary Education Qualifications: Chinese Female cf. National Female Average (\%) (Source: Census data, Statistics New Zealand)

force was at a high of 48 percent. Compared with the country's female average (39 percent full-time: 21 percent part-time; 37 percent not in the labour force; 3.6 percent unemployed), the employment situation of Chinese females was clearly far from satisfactory (Figure 4).

A similar mismatch of educational background and employment has also been revealed in the 1996 and 2001 censuses. This new situation was in direct contrast to the situation before 1987, the period immediately before the arrival of the new immigrants. In those 'pre-watershed years', the employment rate for Chinese females was 13.7 percent, which was much higher than the national average of 4.6 percent for females. More significantly, approximately 18 percent of Chinese females were employed in professional, technical and other related areas, which compared favourably with the national average of 13.8 percent. What statistical figures do not show was that the pre-1987 Chinese females were mostly local-born with long experience in New Zealand, while the post 1987 Chinese females were predominately foreign-born new immigrants. Statistics show that the educational background of Chinese females had 
not changed significantly, but their employment situation had worsened. The explanation could be because the new Chinese immigrant females were not yet fully acculturated and suffered setbacks and possible discrimination from employers who preferred to hire staff with experience in New Zealand.

The current bleak employment situation of Chinese female migrants has been accentuated by their occupational distribution and low income. Similar to the situation of Chinese migrant women in 1987-1996, recent migrants worked in poorly paid occupations (50-59 percent, according to the 2001 and 2006 census). Chinese women working in professional areas accounted for only around 16-18 percent of total employment compared with around 23-25 percent for the New Zealand European-born women. As a result, the average income of Chinese women was around 40 percent lower than the national average income for women.

Despite their excellent educational level, Chinese migrant women have performed poorly in the local labour market. Racial and gender prejudice, prob-

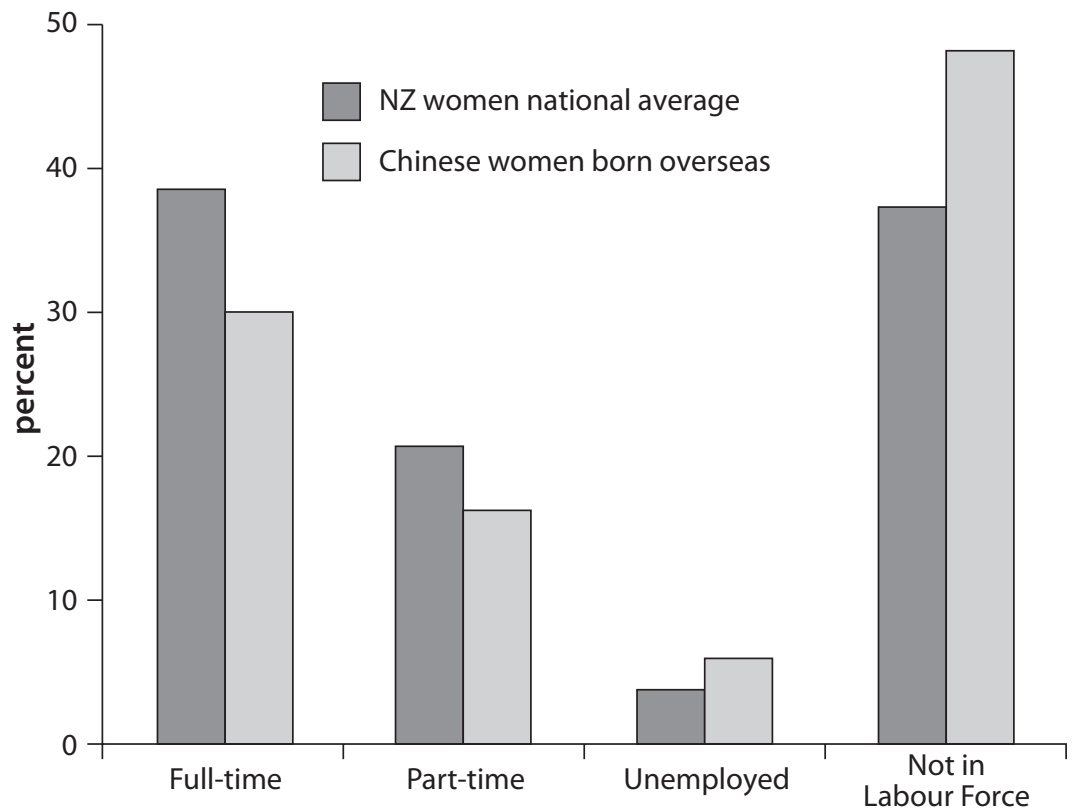

Figure 4. Female work force participation: Chinese cf. National Average (\%) 2006 Census (Source: Statistics New Zealand) 
lems with the English language, and unrecognised foreign qualifications and work experiences were possible factors behind this pattern. Some young women who did not want to accept unrewarding occupations and low incomes undertook retraining to build up their credentials. The 1991, 1996, 2001 and 2006 census data showed that more Asian females attended training courses (including full-time and part-time studies) than the national average for women (Figure 5). Migrants' employment status and income could improve in relation to their time of residence if they obtain a New Zealand tertiary qualification. Therefore, the Chinese migrant women attending local training, most of which (67 percent) were at tertiary levels, were more likely find a better job and earn a future higher income.

As noted above, the employment-related situation of recent Chinese woman migrants seemed to be worse than their counterparts in the 1980s. However,

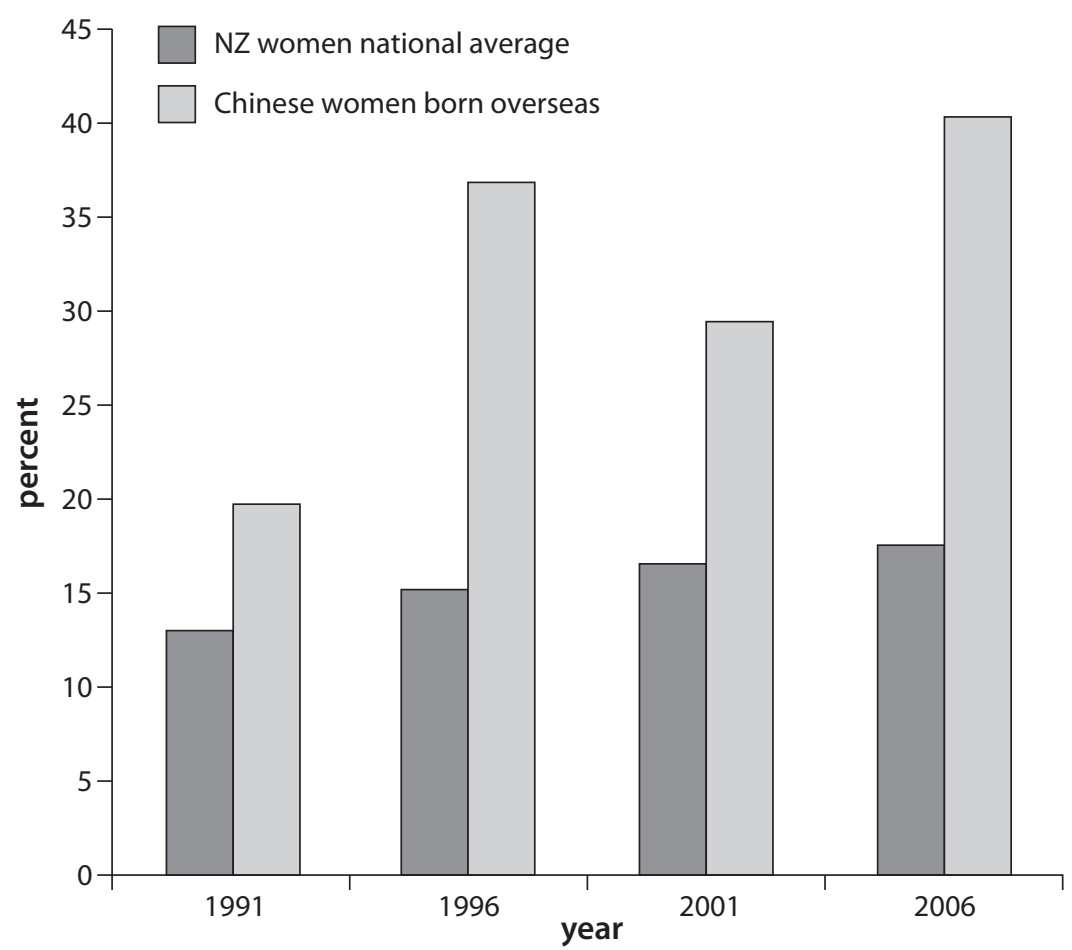

Figure 5. Course Attendance rate (\%) in New Zealand: Chinese female cf. National female average, 1991-2006 (Source: Statistics New Zealand) 
the comparison was not on the same basis. The recent Chinese migrant women were first-generation migrants, who had settled in New Zealand for less than a decade. The 1986 census data reflects the situation of Chinese woman migrants who had resided in New Zealand for a long time with generations of connections in New Zealand society. In conclusion, recent Chinese migrant women have the freedom to choose to migrate or not, are more financially independent, and have more opportunities to attend further training after arrival. Such opportunities did not exist for their early counterparts.

\section{WOMEN IN DIASPORIC FAMILIES}

In a country where the history of nation building has been based on the settlement of incoming British migrants, the circulatory movements of recent Chinese are baffling. One of the most conspicuous elements of this multi-locality community was the presence of the large number of new Chinese female migrants. However, migration has never been a single-direction movement. The migration and settlement patterns of the Chinese needs to be understood within the wider context of New Zealand social and economic development. The impact of globalisation is significant both in generating and accelerating the movement, as well as complicating the pattern of integration of the Chinese as a community into New Zealand life.

The new immigrants' extra-local orientation is because many of them have found the business environment and employment situation uninviting compared to the familiar, vibrant and high-growth economies of East Asia. Scholars studying the new migrant communities of Canada and Australia generally concur that the strength of the Asian economies which created the Asian middle class with its adventurous migrants also placed powerful strings on these same people, pulling them back to Asia. Even during the 'Asian flu' (Asian financial crisis) of the late 1990 os when the Asian economy slowed considerably, many business people continued to see more opportunities in Asia than in their host countries. It is this unwillingness to relinquish a lucrative and familiar market, coupled with the belief that there might be new openings for linkages between their homelands and adopted countries that has given rise to substantial increases in migrants' international travel.

For some less fortunate new immigrants whose new business ventures have never taken root in New Zealand, and for those whose vocational skills were not recognised, multi-locality migration also became a necessity. Faced with the threat of prolonged unemployment and no income, many new Chinese migrants consider that they have no option but to become 'returnees'. Shuttling 
across the Pacific is less an active choice as an 'astronaut' taking advantage of the best of both worlds, but more a survival strategy. The income earner returns to the country-of-origin to pick up their former business or to engage in ventures in a familiar economic climate, and to support family remaining in New Zealand with overseas funds.

All indicators point to the tendency of new Chinese immigrants, both male and female, becoming 'trans-nationals' for whom commuting is the norm. It is highly likely that they will remain bi-local or multi-local, never forfeiting their options of maintaining frequent contact with both their country of origin and their country of adoption. Migration to any particular host country is very often the beginning of 'step-migration' to a third country. Alternatively, return migration is not so much the permanent re-settlement in the county of origin, but in frequently a periodic visit to maintain a diasporic network. The apparent attachment to the place of former residence (China, Taiwan, Hong Kong or other overseas Chinese centres) may not be based on any lingering patriotism. When the convenience of modern jet travel and telecommunication advancements have made trans-Pacific ties much easier to maintain, the former business networks as well as family ties can be nurtured and built on.

The radically changing behaviour of Chinese migrants to Pacific Rim countries has gone hand-in-hand with the changing role of women. At the turn of the century, entire villages in the Pearl River Delta were kept prosperous by remittances from the goldfields of the New World, including New Zealand. In the early years of the twenty-first century, we witness the reverse phenomenon of Chinese men working in Asia where the economy is expanding faster and where jobs are more plentiful, supporting their families in Vancouver, Sydney or Auckland. It is the women who have been playing a key role in fulfilling families' migration plan. In the case of New Zealand, the common practice is that women as the principal applicants stay to satisfy the three-year residency condition in order to obtain a permanent returning visa or citizenship of New Zealand. After securing permanent returning visas or New Zealand passports, the family might reconsider whether to leave or stay. In many cases, it is the women who initiate the idea of returning to the country of origin or stepping into a third country.

Developing simultaneously with this shuttling between the homeland and the new country of adoption is the building up of multi-locality networks amongst members of the migrant's extended family. Contrary to the expectation of chain-migration theorists, the new Chinese New Zealanders' Survey (Ip 2006) reveals that comparatively few new Chinese immigrants have siblings 
and parents staying in New Zealand with them. Instead, many have siblings and parents located either in their country of origin, or in various Pacific Rim countries. For example, respondents to the survey have more of their siblings located in Australia and Canada than in New Zealand. This phenomenon is highly significant and has far-reaching implications for the future of the diasporic network. Modern Chinese females have been playing a crucial role in the formation and maintenance of this network: as initiators, protagonists and active players.

\section{NOTES}

1 The total Chinese population declined sharply from 5,004 in 1881 to 2,570 in 1906. It reached 2,147 in 1916.

2 Decision of Minister, 5 May 1939, C 33/24, cited in Ponton (1946:119-120).

3 Ibid.

4 For example, ten permits per year were allocated to wives of New Zealand born Chinese in 1935; the Chinese were entitled to the old-age pension in 1936 and to social security benefits in 1938 . The poll-tax was declared a blot to New Zealand history in 1944.

5 The 2001 census found that Asians (numbering just below 240,000) have become the third largest ethnic group in the country, edging ahead of 231,801 Polynesians. About half of 'Asians' are ethnic Chinese.

6 For all Census 2006 data see Statistics New Zealand website.

\section{REFERENCES}

Appendices to the Journal of the House of Representatives 1879 D-3.

Bedford, R., E. Ho and J. Lidgard 2000 International Migration in New Zealand: Context, Components and Policy Issues, Hamilton, New Zealand: Department of Geography, University of Waikato.

Brawley, S. 1993 'No "White Policy" In New Zealand: Fact and Fiction in New Zealand's Asian Immigration Record', New Zealand Journal of History, $27(1): 85-100$. 
Chung, R. and F. Walkey 1989 'Educational and Achievement Aspirations of New Zealand Chinese and European Secondary School Students', Social Science Collections, 21(2): 139-152.

Friesen, W. and M. Ip 2001 'The New Chinese Community in New Zealand: Local Outcomes of Transnationalism', Asian and Pacific Migration Journal, $10(2): 213-240$.

Ho, E. 2002 'Multi-local Residence, Transnational Networks: Chinese Astronaut Families in New Zealand', Asian and Pacific Migration Journal, 11 (1):145164.

Ho, E. and R. Bedford 1997 'Astronaut Families: A Contemporary Migration Phenomenon', in East Asian New Zealanders: Research on New Migrants. AsiaPacific Migration Research Network, Albany, Auckland: Massey University.

Ho, E., M. Ip and R. Bedford 2001 'Transnational Hong Kong Chinese Families in the 1990s', New Zealand Journal of Geography, 111: 24-30.

Hom, M. K. 1987 Songs of Gold Mountain, Berkeley: University of California Press.

Ip, M. 1990 Home Away from Home, Auckland: New Women's Press.

Ip, M. 1991a 'Ken Chunyu', in C. Macdonald (ed.) The Book of New Zealand Women, Wellington: Bridget Williams Books:3-6.

Ip, M. 1991b 'Kue Sum Ah-Chan', in C. Macdonald (ed.) The Book of New Zealand Women, Wellington: Bridget Williams Books: 135-137.

Ip, M. 1995a 'Chinese New Zealanders: Old Settlers and New Immigrants', in S. W. Grief (ed.) Immigration and National Identity in New Zealand: One People, Two People, Many Peoples?, Palmerston North, New Zealand: The Dunmore Press Ltd:161-199.

Ip, M. 1995b 'From Gold Mountain Women to Astronauts' Wives', in P. Macgregor (ed.) Histories of the Chinese in Australasia and the South Pacific, Melbourne: Museum of Chinese Australian History: 274-286.

Ip, M. 1996 Dragons on the Long White Cloud, North Shore City, New Zealand: Tandem Press. 
Ip, M. 1998 'New Zealand', in L. Pan (ed.) Encyclopedia of Chinese Overseas, Singapore: Curzon: 286-291.

Ip, M. and W. Friesen 2001 'The New Chinese Community in New Zealand: Local Outcomes of Transnationalism', Asian and Pacific Migration Journal, $10(2): 213-239$.

Ip, M. 2002 'Redefining Chinese Female Migration: From Exclusion to Transnationalism', in L. Fraser and K. Pickles (eds) Shifting Centres: Women and Migration in New Zealand History, Dunedin: University of Otago Press: 14165.

Ip, M. 2003 'Chinese Immigrants and Transnationals in New Zealand: A Fortress Opened', in J. C. Ma and C. Cartier (eds) The Chinese Diaspora: Space, Place, Mobility and Identity, Lanham: Rowman \& Littlefield:339-358.

Ip, M. 2006 'Returnees and Transnationals: Evolving identites of Chinese (PRC) Immigrants in New Zealand', Journal of Population Studies, 33: 61-102.

Murphy, N. 1995 The Poll-tax in New Zealand: A Research Paper, Wellington: New Zealand Chinese Association.

Murphy, Nigel 2000 A Guide to Laws and Policies Relating to the Chinese in New Zealand, 1871-1996. Wellington: New Zealand Chinese Association.

Labour Department, 'Customs Department, Gisborne C-Gs 122/1-3 Box 16 ((New Zealand National Archives).

Labour Department 1950 L1, 22/1/81, 1950 Customs Department Memo C33/253/M, Asian Immigration (New Zealand National Archives).

Ng, J. 1993 Windows on a Chinese Past, Dunedin, New Zealand Otago Heritage Books.

New Zealand Immigration Service (NZIS) 2007 'Trend, Statistics and Summaries', cited 21 October 2008. www.immigration.govt.nz/migrant/general/generalinformation/research/trendsstatisticsandsummaries.htm.

New Zealand Parlimentary Debates 1880, 36: 91.

New Zealand Parlimentary Debates 1907, 142: 839-40. 
Pan, L. The Encyclopaedia of Chinese Overseas, Singapore: Curzon

Ponton, F. A. 1946 'Immigration Restrictions in New Zealand: A Study of Policy from 1908 to 1939', unpublished MA thesis, Wellington: Victoria University.

Price, C.A. 1974 The Great White Walls are Built: Restrictive Immigration to North America and Australasia, 1836-1888, Canberra: Australian Institute of International Affairs in association with Australian National University Press.

Rogers, A. 1996 A Lucky Landing: The Story of the Irish in New Zealand, Auckland: Random House.

Skeldon, R. 1994 Reluctant Exiles? Migration from Hong Kong and the Overseas Chinese, Hong Kong: Hong Kong University Press.

Skinner, G.W. 1976 'Mobility Strategies in Late Imperial China: A RegionalSystems Analysis', in C.A. Smith (ed.) Regional Analysis, Vol. 1. 'Economic Systems', New York: Academic Press:327-64.

Statistics New Zealand. 2001 'National Summary, Ethnic Group'.

Statistics New Zealand, 2007 '2006 Census', cited October 21 2008, www.stats.govt. $\mathrm{nz} /$ census/census-outputs/default.htm.

Statutes of New Zealand 1907 'Chinese Immigrants Amendment Act 1907, vol. 79.

Thomson, B. and Research Unit of the Department of Internal Affairs 1999 Ethnic Diversity in New Zealand: A Statistical Profile. Ethnic Affairs Service Information Series No. 3, Wellington: Department of Internal Affairs.

Vong, C. 2002 'The Impact of Migration on the Chinese Family', New Zealand Journal of Counselling, 23 (1):21-32. 